\title{
The Importance of Agency Law for Indonesia as a Fundamental for Fair Business Activity
}

\author{
Budi Santoso \\ \{budisantosotmg@lecturer.undip.ac.id\} \\ Universitas Diponegoro, Indonesia
}

\begin{abstract}
This article aims to discuss the importance of agency law and assess whether or not Indonesia should have an agency law. The method used is normative juridical by prioritizing secondary data in the form of problematic agency regulations in Indonesia and comparing with agency regulations of others countries, especially the United States. Agents are an integral part of Indonesia's business activities, whether small-scale businesses or large-scale businesses, especially foreign businesses, are entering Indonesia. Agency is a legal relationship between the power of authorizer (principal) and the authorized (agent) party and the potential for legal problems to arise. Indonesia currently does not have an agency law; this can result in the absence of legal certainty for resolving agency problems and no guarantee of a fair solution for the parties. This article considers the Indonesian government's need to enact an agency law immediately.
\end{abstract}

Keywords: Law, Agent, Principal, Indonesia

\section{Introduction}

Indonesia does not yet have an agency law that regulates the legal relationship between principals and agents, even though many countries already have agency laws, such as the United States and Agency Law. Malaysia has an agency law that is regulated in part X of the Contract Act 1950. Singapore in Ch. 15 is also regulated regarding agency. European Communities is organized into 86/653/EEC on self-employed commercial agents. In the United Kingdom, the agency is regulated in the National Law in the Commercial Agents Regulations of 1993. Meanwhile, the India agency is regulated in Section 182 of the Contract Act 1872.

In Indonesia, the regulations governing agents are Regulation of the Minister of Trade of the Republic of Indonesia No. 11/M-DAG/PER/3/2006 regarding the terms and procedures for the issuance of registration certificates for agent distributors of goods and or services. This regulation is administrative and not substantive, so that the rights and obligations of principals and agents, liability for third parties for losses suffered by third parties, are not regulated in this regulation.

Indonesia's agency format has grown faster than the set of regulations that underpin it. The set of rules that form agency in Indonesia is still based on general rules, namely, rules regarding agreements, rules relating to granting authorizer's power, and administrative nature from the Indonesian Ministry of Industry and Trade.

The absence of agency law in Indonesia makes legal relations between the parties not guaranteed to be resolved fairly. In the United States, the problems that arise in the agency sector 
are several rules; agency law, contract law, tort law. Apart from that, the Restatement (Second) of Agency also pays close attention.

This article aims to discuss the basic principles, importance, and problems that can arise in agency relationships and the rules that are the basis for solving these problems.

\section{Basic Principles and Importance of Agency}

According to Hemphill and Long [1], The basic philosophy of agency is rooted in the ancient Roman legal tradition, which in Latin: "Qui facit per alium facit per se" which mean "who does the act/action through another party is like doing one's deed/action" [2]. Likewise, Dale Baze states that an agency is a legal relationship whereby one person, an agent, is authorized by another, a principal, to act on that person's behalf, and is empowered to do what the principal could lawfully do in person [3].

In an agency agreement, the principal gives the agent authority to carry out specific jobs under supervision and responsibility. However, certain conditions still require the principal to do the job himself and cannot be delegated to the agent. The principal's obligation to carry out his actions is often known as a non-delegable obligation, which is a specific obligation that requires the principal to do it himself, for example, making or preparing a statement under oath, signing a policy, making a contract with lawyers, being present as a witness in court etc. [4][5]. Thus, there are three main parties in the agency, namely the principal, agent, and the third party.

Principals, often equated with masters or employers, are parties who have the right to give instructions to an agent, whether to do specific legal actions and how these actions should be done, while the other party is an agent. Agents themselves can be grouped into the class's servants or employees. Besides, there are other parties between the principal and the agent's agency relationship, namely the third party.

Lieberman and Siedel [6] describes the relationship between the parties in an agency relationship as shown in the figure 1 .

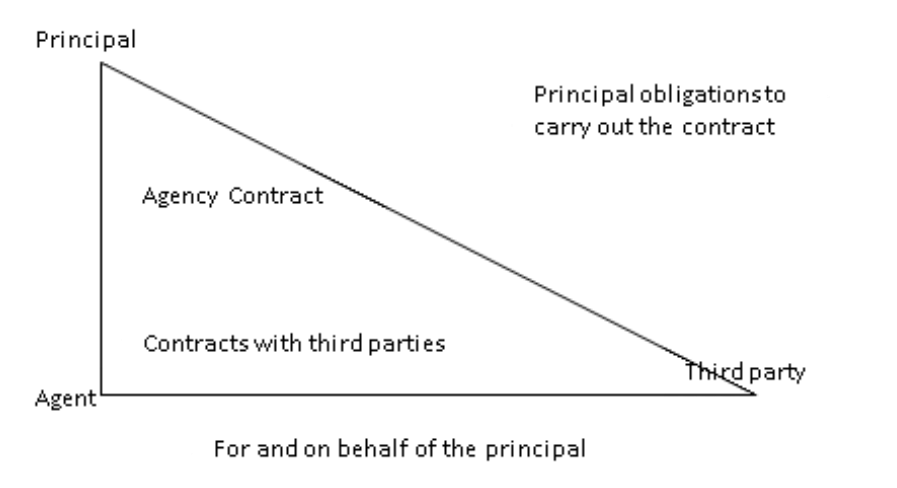

Fig. 1. Agency relationship.

Based on the agency's basic philosophy, the agency relationship is built on the basic principles of trust (fiduciary duties) and the principle of respondeat superior. First, the basic principle of fiduciary duties, in Black's Law states that "agency is the fiduciary relation which 
results from the manifestation of consent by one person to another that the other shall act on his behalf and subject to his control, and consent by the other so. to act" [7].

Fiduciary duties arise when someone delegates or authorizes another person to perform specific legal actions for and on behalf of and for the benefit of the party giving the authority. This legal relationship creates a moral obligation to obey one another, which is often known as the doctrine of fiduciary duties.

Davidson explains fiduciary duty, the legal duty to exercise the highest degree of loyalty and good faith in handling the person's affairs to whom the duty is owed [8][9]. In Black's Law, it is explained that a person was having duties involving good faith, trust, extraordinary confidence, and candor towards another. A fiduciary "includes such relationships as executor, administrator, trustee, and guardia" [7].

Thus, the fiduciary is the soul or spirit of the agency relationship that is formed between the principal and the agent. In terminology, the word fiduciary can be used both in context as a noun or adjective. When fiduciary is defined as a noun, it refers to a person who should take action for and on behalf of others and other parties' benefit. When the word is interpreted as an adverb, it refers to a relationship of trust, which means that there is a fundamental principle in that relationship, namely trust, and confidence [10].

Second, the doctrine of respondeat superior. The point stated that the principal, employer, employer, was responsible for losses suffered by third parties due to the agent's mistakes, assistant, worker, as long as the act was committed within their work scope.

Thus, the doctrine of respondeat superior is not based on the idea that the master has committed an error, but this is a specialty of a strict liability doctrine, that responsibility for an adverse action is only based on the occurrence of a particular action or action and is not based on mistakes committed by people who have to compensate for specific actions.

The simple philosophy is that the master has paid the servant to do specific actions. If the helper makes a mistake, the master should pay compensation that arises because of the servant's actions. In other words, someone should pay, and the master is the party in the best position to make the payment and bear the loss. However, the respondeat superior requires a wrongful act, which is wrong according to the Law by the assistant.

The superior respondeat doctrine is only applied to servants and not non-servants because the master does not have the right to exercise control over non-servants, and because there is no authority to supervise the acts committed by the servant, this party is not the master

\section{Agency Problematics (Agency Problems)}

Armour et al. [11], in their writings, stated that agency problem is often referred to as the jargon "an agency problem" or "principal-agent problem", also Dorsey [12], in his article highlighting "agency problem" concerning alcohol distribution in the United States. Cohen [13] examines the collusion problem in agency law. Rasmusen [14] highlighted agency problems concerning Agency Law and Contract Formation.

The absence of agency law in Indonesia is substantial means that the agency's substantial problems in Indonesia do not have legal certainty, resulting in an inability to provide justice to the parties. There are many substantial problems in the agency sector, but in this article, we limit the substance problem of who the agent is, the principal, the parties' rights and obligations, the principal's liability for losses incurred by the agent to third parties. 


\subsection{Substance Problems Who is the Agent}

In the Regulation of the Minister of Trade of the Republic of Indonesia No. 11/MDAG/PER/3/2006 regarding the terms and procedures for the issuance of registration certificates for agents or distributors of goods and or services. Article 1 states that an agent is a national trading company acting as an intermediary for and on behalf of the principal based on an agreement to carry out marketing without transferring rights over physical goods and or services owned/controlled by the principal who appointed it.

Based on the provisions stated in Article 1 above, the agent has characteristics; Agent is a national trading company, acting as an intermediary, acting for and on behalf of its principal. The principal and the agent's legal relationship is stated in an agency agreement. The purpose is to market goods or services, and there is no need to transfer rights over goods or services authorized by the principal.

In Black Henry Campbell [7], the meaning of the agent is:

"Agent, a person authorized by another (principal) to act for or in place of him, trust another's business. One represents and acts for another under the agency's contract or relation. A business representative, whose function is to bring about, modify, affect, accept performance of, or terminate contractual obligations between principal and third persons. One who undertakes to transact some business, or to manage some affair, for another, by the authority and on account of the letter, and to render an account of it. One who acts of or in place of another by authority from him; a substitute, a deputy, appointed by principal with power to do the things which principal may do. One who deals not only with things, as does a servant, but with a person, using with own discretion as to means, and frequently establishing contractual relations between his principal and third persons. One authorized to transact all business of principal, or all principal's business of some particular kind, or all business at some particular place”.

If the provisions regarding Agent in Indonesia are compared with the definition of the agent in the Black's law dictionary, as is also used in agent law in the United States, basically there are similarities in several things, namely:

a. The agent acts primarily for and on behalf of its principal;

b. Most of the legal relationships between the principal and the appointed agent are stated in the agreement, only in the provisions of Regulation of the Minister of Trade (Permendag) No. 11/2006 does not explicitly state that it is stated in a written agreement;

c. The agent does not require the transfer of rights to goods or services entrusted to him by the principal;

The difference between an agent's meaning in Indonesia and the U.S. lies in who can act as an agent. Following the provisions of the 2006 Regulation of the Minister of Trade above, the agent must be in the form of a business entity, namely a national trading company, which cannot be an individual. It is understandable because the regulation is only explicitly made to regulate trade intermediary companies, domestic trade, and foreign trade, which requires that they be in the form of a business entity. Meanwhile, an agent's concept in agency law in the U.S. can be carried by an individual, as long as the person concerned is classified as a person who can sign a contract, meaning that he is not under interdiction, children, crazy, and soon. Thus, as referred to in the 2006 Minister of Trade Regulation, the agent's concept is indeed 
narrowed down to only being a company and not aimed at individual agents. It means that an agent in the form of individual outside the context of the agent's conversation, as mentioned in the 2006 Minister of Trade Regulation.

According to the 2006 Minister of Trade Regulation, an agent's concept is the status of a trade intermediary, which of course becomes an intermediary between the principal and a third party. It means that an agent's existence is indeed associated with trading or business activities and is not related to an agent's appointment outside of trading activities. Whereas in the U.S., the appointment of an agent, although generally related to business activities, is possible to appoint an agent for matters that are not related to business activities. It can happen simply by making a power of authorizer. For example, asking for help from fellow students to return books to the library has been an agency in its simplest form. Furthermore, the factors or aspects of the obligation to ask for principal approval in several ways, namely the authority to supervise or control the agent's actions in carrying out his duties by the principal, and how much authority to exercise discretion from the agent, is also an indicator of the presence of agents in the U.S. It is different from the definition of an agent as stated in the 2006 Minister of Trade Regulation above, which is only given the meaning of a national trading company acting as an intermediary for and on behalf of the principal based on an agreement to carry out marketing without transferring rights to physical goods and or services owned/controlled by the principal who appointed it.

Another aspect that distinguishes agency in Indonesia from that in the U.S. is emphasizing the principal and the agent's legal relationship. In the agency concept in the U.S., it is explicitly stated that the legal relationship between the two is based on fiduciary duties, something that is not explicitly stated in the agency relationship as stated in the 2006 Minister of Trade Regulation.

In the agency concept in the U.S., the word fiduciary can mean as an adjective "it means of the nature of a trust; having the characteristics of a trust; analogous to a trust; relating to or founded upon a trust or confidence".

Thus, it can be concluded that the definition of an agent in the 2006 Minister of Trade Regulation is only interpreted as a noun, not interpreted as an adjective.

\subsection{Substance Problems Which are the Principals}

Article 4 of the Regulation of the Minister of Trade of 2006 states that the appointment of agents, sole agents, distributors, sole distributors can be carried out by producer principals, supplier principals based on the approval of producer principals, small investment companies engaged in trading as distributors/wholesalers, offices representatives of foreign trade companies.

In Black's Law, the term "principal" describes one who has permitted or directed another (agent or servant) to act for his benefit and subject to his direction and control, such that the acts of the agent become binding on the principal. Principal includes in it meaning the term "master", a species of the principal who, in addition to other control, has a right to control the physical conduct of the species of agents known as servants, as to whom special rules are applicable concerning harm caused by their physical acts.

The agency system in the United States does not differentiate whether it is a producer principal, a supplier principal, a FDI (Foreign Direct Investment) company, or a representative office of a foreign company. Whatever the form of business, business specifications, there is no question, the most important thing is that the party who will act as the principal is the party who meets the requirements to act as the principal, namely the party who appoints another person to 
represent him, for and on his behalf has committed specific legal actions, under the order, command, as well as supervision. Who can act as principal? Everyone except minors or minors can make contracts, employ helpers in their capacity as agents or non-agent servants, and have the legal capacity to give consent operational at the acolytes.

Thus, the United States system puts more emphasis on its substantive issues to be able to act as a principal. Whereas in Indonesia, perhaps the separation of principal forms into several fields (producer principal, supplier principal, etc.), it is indeed useful administratively for the government to further regulate, but substantively it cannot be found in fact who can act as principal in general in world agency in Indonesia.

Futhermore, it can be concluded that the regulation of the Minister of Trade of Indonesia does not regulate who can acts as principal substantively, but only administrative matters as principal are regulated.

\subsection{Problems of Rights and Obligations of the Parties}

Article 20 of MOT No. 11/M-DAG/PER/3/2006 states that:

a. Agent, sole agent, sub-agent, distributor, sole distributor, or sole sub-distributor is entitled to education and training to improve skills and after-sales service from the principal and regularly receive information on product development.

b. If necessary, agents, sole agents, distributors, sole distributors may employ foreign national experts in the technical field under applicable regulations.

c. Agent, sole agent, distributor, and sole distributor are obliged to protect the principal's interests and confidentiality against the goods and/or services that are brokered following what has been agreed in the agreement.

d. A producer principal supplying goods with sustainable use within a minimum time limit of 1 (one) year is obliged to provide spare parts or after-sales service and fulfill the guarantee or guarantee following the agreed agreement.

The formulation of the provisions of Article 20 above is so simple. It does not mention in full the parties' rights and obligations, in this case, the agent, distributor with the principal, the principal's rights and obligations, the rights and obligations as an agent, and the distributor many other regulations have formulated. The possibility of the government only limiting matters deemed necessary for the government, to be formulated in regulations following its authority, namely the issue of education and training from principals, as formulated in Article 20 above, while other rights and obligations which affect only two parties are fully delegated to be upheld in the agreement made by the parties. In the agency law system in the United States, the rights and obligations of principals and agents are regulated.

\subsubsection{The Agent's Liability to the Principal}

If the agency is stated in a written agreement or contract, the parties must comply with the mutually agreed agreement. It does not matter whether the agency relationship is written, contractual, or not. The general rules relating to the agency stipulate fiduciary duties, namely that the agent has "debt" with the principal. This obligation arises through an agency agreement. These obligations are because the agency relationship is a relationship of trust and confidence. Fiduciary duties mean a person in a position of trust and confidence, a person in a position of trust and confidence. Also, the agent may be obliged to comply with obligations arising from coercive legal provisions unless the parties agree otherwise. 
There are several obligations attached to the agent to its principal, namely:

a. Duty of good faith;

b. Duty of loyalty;

c. Duty to obey instructions;

d. Duty to notify the principal;

e. Duties to account;

f. Duty to conduct business with reasonable skill and diligence;

g. Duty to communicate and obtain instructions in case of difficulty;

h. Duty to segregate funds;

i. Duty not to make any secret profit;

j. Duty not to delegate authority;

k. Duty not to use information obtained in the agency's course against the principal.

\subsubsection{Principal's Obligations to Agents}

Except for gratuitous Agent, Agent has the right to get compensation from the principal as agreed in the agency agreement. Gratuitous agents are that person volunteered to help another, and the person being helped accepted this assistance, also includes a person who volunteers services without an agreement or an expectation of payment. Some agency agreements entitle the agent to special compensation, such as sales commissions. Other obligations that apply to principals in their agents are to provide a safe, comfortable place to work and provide security for tools and equipment needed to work. In general, the principal's obligations to the agent are as follows:

a. Compensation, the principal must pay the agent for all services that have been performed as agreed in the agency agreement. Thus, compensation means a payment from the principal to the agent for services (payment of service). This compensation may consist of customary compensation and commission;

b. Reimbursement, the principal must reimburse all costs incurred by the agent concerning doing work that the principal instructs the agent. The obligation to replace all these costs is called a reimbursement. However, the principal is not obliged to reimburse the agent's costs if it occurs due to the agent's mistake or carelessness in carrying out his work. For example, the agent transfers something of value to the wrong person. The agent does not have the right to ask for reimbursement for the costs incurred because of his mistakes.

c. Indemnity, the agent has the right to guarantee that all instructions given by the principal are following applicable legal provisions. The agent also has the right to guarantee that he will not be involved in taking personal responsibility if he has performed his duties following the instructions given to him. The agent's right to get a guarantee of protection for losses that arise in carrying out his duties from the principal is called indemnity.

d. Cooperation, the principal should cooperate with his agent and assist the agent in carrying out the work delegated to him. Principals are not allowed to take actions that prevent delegated work to their agents. For example, when a principal gives rights to an exclusive territory agent and creates exclusive territorial rights, the principal cannot do business in competition with his agent or appoint other parties or allow other parties to compete with the agent he appointed. If the principal does this, then the principal is responsible for the agent's losses, whether in the form of failure to sell or loss of profit.

e. Save working conditions, generally accepted laws require the principal to provide security for the equipment that will be used by agents and employees and comfortable working conditions for agents and employees. For this reason, the principal has the right to check the 
agent's workplace and his employees and warn the agent and employees who help him with matters relating to areas he deems unsafe.

\subsection{Principal Liability for Third Party Losses}

Regulation of the Minister of Trade (Permendag) No. 11/M-DAG/PER/3/2006 does not regulate matters relating to principal liability for losses suffered by third parties due to agents' actions.

In the agency law system in the United States, the principal is responsible for what has been stated in the contract and responsible for the mistakes (tort) made by the agent appointed. Following the Respondeat Superior doctrine, if an agent takes action within the scope of his work, the principal will be responsible for losses incurred to third parties caused by the agent's actions. The principal is also responsible for the third party's losses due to the agent's negligence, but the principal has the right to demand compensation from the agent who made the negligence.

The principal who has delegated the agent's authority to make a contract with a third party will be responsible for anything that results from signing the contract later. Thus, the third party can demand the contract's implementation and demand compensation if the principal fails to carry out the contract. In this case, the appointed agent may also be responsible for a third party in certain circumstances.

Thus, as a general rule, the agent is not personally responsible for all contracts he makes with third parties on behalf of his principal. However, there are exceptions to this generally accepted principle in some countries, such as the Law in England, which states that an agent of a principal who resides outside the U.K. is responsible even though he clearly signs a contract identifying himself as an agent.

In the United States, there are some exceptions to the generally accepted rules above, namely [6]:

a. When the agent provides services, which are classified as undisclosed or partially disclosed by the principal;

b. When the agent does not have authority over the action taken or the action exceeds the limit of his authority;

c. If the agent enters into a contract with a third party on his own behalf.

The agent's liability to third parties is based on the agency's classification agreement signed with the principal. Agency agreements can be classified into three groups: fully disclosed, partially disclosed, and undisclosed.

A fully disclosed occurs when the third party who signs the contract knows or has sufficient knowledge that the agent in carrying out his work acts as an agent of a specific principal, the principal's identity is known to the third party, whether it is notified by the agent or through other means. In cases like this, the contract is actually made between the principal and the third party. Thus, the principal is fully responsible for the third party signing the contract because the third party is willing to sign the contract because of the principal's reputation. The entire contract agent is not responsible for the third party unless the agent guarantees in the contract signed by the third party that the principal will carry out the contract.

Partially disclosed occurs when an agent in carrying out the duties delegated by the principal to him shows his identity as an agent and does not reveal his principal's identity. The third parties who make transactions with agents do not know about the principal's identity through other sources. The agent's failure to notify the principal's identity may occur due to several reasons, including: 
a. The principal gives instructions to agents not to disclose or disclose the identity of the principal to third parties;

b. Agent forgets to disclose the identity of the principal to the third party.

In the event of a situation as above, both the principal and the agent are jointly responsible for the third party; this is because the third party's motivation to sign the contract is based solely on the reputation and integrity of the agent, while the principal is not identified.

Undisclosed agency occurs when a third party is not aware of either the agent or the principal's identity. In such circumstances, the principal is called an undisclosed principal. An agency agreement that is not told who the principal and the agent are is against the Law (unlawful). The undisclosed agency usually occurs or is used when the principal feels that the clause in the contract he makes will be changed if the principal's identity is known. For example, a wealthy person is likely to ask his agent to hide his identity when he asks his agent to buy a specific house he wants; this is because if the home seller knows the identity of the affluent prospective buyer, it is likely that the seller will increase his bid price from usually.

The undisclosed agency holds both the principal and the agent responsible for the third party signing the contract. By not disclosing the agent's status to the third party, the agent acts as the principal to the third party, while the principal has delegated authority to the agent; thus, both the principal and the agent are responsible for the third-party conducting transactions with the agent. An agent who has incurred costs in doing work delegated by the principal to the agent is entitled to reimbursement of all principal expenses.

Concerning the issue of liability, the general principle applies that whether the principle, in this case, is disclosed, partially disclosed, or undisclosed ultimately depends on the third party's knowledge while conducting the transaction with the agent.

If the third party knows, or ought to know, that the agent has committed an act in his position as the principal's agent, and the third party knows the principal's identity, this is classified as a disclosed principal. If the third party knows or knows that the agent is acting as agent for the principal, but the third party does not know its identity, this is classified as partially disclosed. If the third party does not know or improperly knows that the agent is acting in the principal's interest, then this is classified as an undisclosed principal.

The agent appointed by the principal to perform specific legal actions for and on behalf of the principal in conducting transactions with third parties may cause losses to the third party. Losses incurred to a third party due to the agent's actions can qualify into several classes of action, namely, the tort of the agent (error), negligence, intentional torts (mistake intentionally), or caused due to fraud [15][16].

\subsection{Indonesia and the need for an Agency Law}

The need for an agency law in Indonesia is urgent to realize considering its existence is inseparable from a series of business activities in Indonesia, both small scale and large scale, both for products and services. Almost all matters relating to the company, both the company's existence and matters relating to the activities of the company, have received adequate regulations in the form of laws. For example, laws governing the existence of business entities, such as the Law on LLC (Limited Liability Company), Cooperatives, SOEs (State-Owned Enterprises). Laws relating to company activities, such as the compulsory company registration law, the company documents law, the intellectual property law, the bankruptcy law, and the suspension of debt payment obligations and soon. However, the Law that regulates the relationship between a company and its agent or distributor has not been regulated in the form of a law. 
If Indonesia is to make a law in the agency sector, what has been drafted in the United States in the form of Restatement of Law-Agency, Restatement (Third) of Agency Current through April 2006, can be used as a comparison.

In the Restatement of Agency, the agency arrangement is grouped into chapters divided into several topics.

a. Chapter I. Introductory Matters;

b. Chapter 2. Principles of Attribution;

c. Chapter 3. Creation and Termination of Authority and Agency Relationships;

d. Chapter 4. Ratification;

e. Chapter 5. Contracts and Other Transactions with Third Parties;

f. Chapter 6. Torts- Liability of Agent and Principal;

g. Chapter 8. Duties of Agent and Principal to Each Other.

The Introductory Matters sub contains matters relating to terminology and definitions. The definition regulates the boundaries, the scope of the central theme used as the object of regulation, namely regarding the meaning of the agent referred to in the Law. Simultaneously, the terminology provides limitations regarding several things that are always related to the main object, namely agency. Thus, terminology regulates many things, whereas definition regulates only a few things.

The definition is only given for agency and manifestation in the agency's restatement. Agency in the Restatement of Law - Agency is given a basic definition as a relationship built based on trust that arises when a person (principal) gives explicit consent to the other party (Agent) to carry out specific actions for and on behalf of and under the supervision of the principal and for in this case the agent expressly agrees or gives his consent in other ways to commit certain acts. While the manifestation emphasizes that for the existence of an agency relationship, it is required that the parties, either the principal or the agent, must show a statement that expressly approves the agency relationship, there must be an intention to give authority to the agent for the principal. There must be an intention to approve it receive authority to perform specific legal actions for agents. A clear statement can be shown through a written agreement, words, or other actions.

Terminology defines the meaning of many things related to the agency in general, and this can be sure to be found in many articles of the agency law. Several things that need attention and need explanation in terminology are related to many terms related to Subagent; Coagents; Disclosed, undisclosed, partially disclosed principal; Unidentified Principals; Gratuitous Agent; Authority, implied authority, express authority; Actual authority, apparent authority; Estoppel; Respondeat superior; Fiduciary duties; Notice; Person; Power given as security; authorized Power; Superior and subordinate coagents; Trustee and agent trustee.

The principles attribution section is the central part of the regulation regarding agency related to the agency relationship's basic principles: the relationship between the principal and the agent and vice versa and the relationship between the two with third parties. These basic principles are the principal capital in relation to problems that may arise in the agency relationship, whether possible problems arising between the principal and the agent, or between the agent and a third party, or between the principal and the third party, or between the third party and the principal and his agents. Thus, the role of principles attribution is so significant because it will be used as the primary reference for solving problems that may arise; the absence of regulating some principles in the attribution principles will lead to different interpretations when a dispute arises in court a later date. For this reason, accuracy, thoroughness, and prudence are the main assets in formulating what should be formulated in this segment, and a broad 
understanding of the substance, contributing to formulating the basic principles of agency relations.

The main object of the agency relationship between the principal and the agent is a matter related to the authority that will be delegated from the principal to the agent. Thus, the authority issue deserves to be placed as the central part of the attribution principles segment, the next new one related to doctrines related to agency issues. In the Restatement of Agency Law in the U.S., principles attribution contains only two main parts: actual authority and related doctrines.

Actual authority is explained that the agent's actions are said to be the actual authority if the agent's actions or actions will bring legal consequences or legal consequences for the principal. Next, matters related to the scope of actual authority, apparent authority, and response superior are also regulated. In the related doctrines section, some things related to agency doctrines are explained: estoppel to deny the existence, liability of disclosed principal, restitution of benefit. Estoppel, to deny agency relationship, provides an arrangement that aims to prevent agents from refusing to be responsible for third parties by denying the existence of an agency relationship with their principals.

Liability of Undisclosed Principal, this provision regulates matters relating to the principal's responsibility to third parties for contracts made by their agents carried out outside their authority limits. In contrast, the third-party intends to enter into a contract with the agent itself. Due to their ignorance of the principal's identity, the third party can sue the principal. However, in such a condition, rules must be made that limit the third party's rights to be able to file a lawsuit against the undisclosed principal. First, a third party cannot sue a principal who has good intentions, and the principal has cleared the matter with his agent. Second, the third party cannot sue the principal if the third party has decided to solve the problem with the agent and not with the principal.

Restation of benefit, if the principal earns income in an unfair way or through fraudulent ways through an agent's actions, then the principal must be responsible for claims of income obtained unfairly.

The section on the creation and termination of authority and agency relationships regulates how it is formed or how agency relationships arise between the principal and the agent. For the next step, several matters relating to the termination of the agency relationship between the principal and the agent are regulated.

This sub is divided into several sections or topics:

a. Topic 1. Creating and Evidencing Actual Authority;

b. Topic 2. Capacity to Act as Principal or Agent;

c. Topic 4. Termination of Agent's Power;

d. Topic 5. Agents with Multiple Principals.

Creating and Evidencing Actual Authority, this section regulates several matters relating to agency relationships between principals and agents. The agency relationship does not require a specific legal form; thus, it can be stated in a written form or orally. However, provisions can be made that require the agency relationship to be stated in a standard form, namely in writing or certain records for specific agency fields, or agency relationships that are longer than one year may be required in written form. For this reason, it must be affirmed in the regulations that the absence of such a legal form or a written form or certain records that regulate the agency relationship results in the principal not being bound by the agent's actions.

Capacity to Act as Principal or Agent, this section regulates the requirements that must be met to act as a principal or as an agent. In some cases, exceptions must also be regulated; for example, can minors act as agents or principals? 
Termination of Agent's Power, this section regulates how agency relationships end. This segment can be divided into three parts, namely Termination of Actual Authority, Termination of Apparent Authority, Termination of Power Given as Security, or Irrevocable Proxy.

Actual authority requires a clear statement of consent from the principal, which must be communicated to the agent. As for apparent authority, the principal's agreement statement must be communicated to a third party. Actual authority is the delegation of authority received by the principal's agent, while the principal's authority is called the express authority.

Sometimes some agents do not have actual authority but can still give the impression that the agent has the authority and a third party trusts this. Agency rules still allow binding principles based on apparent authority to protect third parties in a situation like that.

Apparent authority arises when a principal's actions cause a third party to believe that the agent is given the authority to take specific actions on the third party. It needs to be emphasized that "apparent authority" only occurs in situations where there is an impression of authority and not in situations where there is the actual authority, which happens or is created by the principal. Meanwhile, irrevocable proxy concerns relate to irrevocable power in the agency relationship between the principal and the agent.

\section{Conclusion}

Indonesia immediately needs an agency law to provide a legal basis for agency business activities already rife. Indonesia can use the United States Agency Law as reference material for making Indonesian agency laws, given the complexity of the United States Agency Law's content.

\section{References}

[1] C. F. Hemphill and J. A. Long, Basic business law. Prentice Hall, 1994.

[2] G. A. Jentz, K. W. Clarkson, and R. L. Miller, West's business law. West Group, 1987.

[3] D. Baze, Common Law of Agency, a Supplemental Chapter for Oklahoma Real Estate Principles. B\&B Publishing, 2009.

[4] T. Bowers, J. P. Mallor, J. Barnes, and A. W. Langvardt, "Business Law, The ethical, global and e-commerce environment." Mc Graw Hill Irwin, 2004.

[5] M. Fuady, Teori-teori Besar Dalam Hukum: Grand Theory. Jakarta: Prenada Media, 2014.

[6] J. K. Lieberman and G. J. Siedel, Business law and the legal environment. Harcourt College Pub, 1992.

[7] M. A. Black Henry Campbell, Black's Law Dictionary. St. Paul, Minn: West Publishing, 1991.

[8] D. V Davidson, L. M. Forsythe, and B. E. Knowles, Business law: Principles and cases in the legal environment. Wolters Kluwer Law \& Business, 2015.

[9] F. P. Kalalo, "Implementation of Environmental Law in Indonesia Business Law Perspective," JL Pol'y Glob., vol. 51, p. 21, 2016.

[10] R. L. Miller and G. A. Jentz, Business Law Today: Alternate Essentials Edition: Text \& Hypothetical Examples--legal, Ethical, Regulatory, and International Environment. West Publishing Company, 1997.

[11] J. Armour, H. Hansmann, and R. Kraakman, "Agency problems, legal strategies, and enforcement," 2009.

[12] J. D. Dorsey, "Agency theory and alcohol distribution: A framework for public policy discourse," J. Mark. Dev. Compet., vol. 8, no. 3, p. 59, 2014. 
[13] G. M. Cohen, "The Collusion Problem in Agency Law," Univ. Virginia Sch. Law, Leg. Stud. Work. Pap. No. 00-2, 1999.

[14] E. Rasmusen, "Agency law and contract formation," Am. Law Econ. Rev., vol. 6, no. 2, pp. 369409, 2004.

[15] J. B. Smith, Business Law in California. 1975.

[16] B. Glassburner, The economy of Indonesia: selected readings. Sheffield; Equinox Publishing, 2007. 